М. С. Бычкова

Байкальский государственный университет, г. Иркутск, Российская Федерация

T. В. Сорокина

Байкальский государственный университет, 2. Иркутск, Российская Федерация

\title{
ОСОБЕННОСТИ ПРОГНОЗИРОВАНИЯ И ПЛАНИРОВАНИЯ ДОХОДОВ КОНСОЛИДИРОВАННОГО БЮДЖЕТА СУБЪЕКТА РОССИЙСКОЙ ФЕДЕРАЦИИ НА ОСНОВЕ РЕГИОНАЛЬНОЙ УПРАВЛЯЮЩЕЙ МОДЕЛИ
}

АНнОтАЦИЯ. Необходимость повышения точности бюджетного планирования обусловила активизацию исследования научно-методических положений и практических проблем стратегического планирования на региональном уровне. Прогнозирование и планирование доходов консолидированного бюджета субъекта РФ с использованием межотраслевых балансов региональной экономики обеспечит полноту и достоверность бюджетных данных. Анализ выполнения плановых показателей доходов консолидированного бюджета региона позволил установить причины отклонений и аргументировать реализацию территориально-отраслевого подхода в бюджетном планировании. На основе изучения свойств показателя «доходы консолидированного бюджета субъекта Российской Федерации» обосновано его максимальное соответствие для применения в региональной управляющей модели. Раскрывается понятие прогнозирования доходов консолидированного бюджета субъекта РФ и рассматриваются особенности их планирования. Как результат интеграции стратегического и бюджетного планирования представлен алгоритм встраивания параметра «Доходы консолидированного бюджета субъекта РФ» в региональную управляющую модель и дана характеристика его этапов.

кЛючЕВЫЕ слОВА. Прогнозирование; бюджетное планирование; стратегическое планирование; доходы; консолидированный бюджет; субъект Российской Федерации; региональная управляющая модель.

ИНФОРМАЦИЯ О СТАТЬЕ. Дата поступления 9 марта 2017 г.; дата принятия к печати 23 марта 2017 г.; дата онлайн-размещения 31 марта 2017 г.

M. S. Bychkova Baikal State University, Irkutsk, Russian Federation

T. V. Sorokina

Baikal State University, Irkutsk, Russian Federation

\section{FEATURES OF FORECASTING AND PLANNING OF INCOME IN CONSOLIDATED BUDGET OF THE RUSSIAN FEDERATION ENTITY ON THE BASIS OF REGIONAL OPERATING MODEL}

\begin{abstract}
Need for increasing accuracy of budget planning has caused activation of investigating scientific and methodical provisions and practical problems of strategic planning at the regional level. Forecasting and planning the income of the consolidated budget of the territorial of the Russian Federation entity with use of inter-industry balances of regional economy will provide completeness and reliability of the budgetary data. An analysis of implementing the planned indicators of the regional consolidated budge income has allowed to establish the causes of deviations and to argue in favor of reason realization of territorial and branch approach in the budget planning. On the basis of investigating the indicator features for "the incomes of
\end{abstract}

\section{Baikal Research Journal}


the consolidated budget of the Russian Federation entity" the article substantiates its maximum compliance for using in the regional operating model. It reveals the concept of forecasting the income of the consolidated budget of the Russian Federation entity and considers the features of their planning. As a result of integration of strategic and budget planning, the article presents an algorithm of embedding the parameter of "Income of the Consolidated Budget of the Russian Federation entity" into the regional operating model and gives the characteristic of its stages.

KEYWORDS. Forecasting; budget planning; strategic planning; income; consolidated budget; Russian Federation entity; regional operating model.

ARTICLE INFO. Received March 9, 2017; accepted March 23, 2017; available online March 31, 2017.

Возрастающая роль стратегического планирования в формировании экономической политики предъявляет все больше новых требований к деятельности органов государственной власти субъектов Российской Федерации, органов местного самоуправления, направленной на решение задач устойчивого социально-экономического развития территории. Так, в соответствии с Федеральным законом «О стратегическом планировании в Российской Федерации» от 28 июня 2014 г. № 172-Ф3 результатом деятельности участников стратегического планирования является достижение целевого состояния экономики и социальной сферы. Наиболее точно сконструировать возможные (альтернативные) перспективы позволяет метод межотраслевого анализа - межотраслевой баланс экономики, разработанный В. В. Леонтьевым [1, с. 11], который в сочетании с национальной системой информации может служить основным инструментом стратегического планирования.

Разработка и внедрение межотраслевых балансов на уровне регионов обеспечат получение достоверных показателей, характеризующих социально-экономическое развитие субъекта РФ, детализированных по секторам экономики и по муниципальным образованиям [2, с. 105-112]. Они могут считаться прогнозным фоном для изучения будущих состояний бюджетных параметров, в том числе доходов консолидированного бюджета субъекта РФ как «основного показателя развития региона» [3, с. 235].

В целях совершенствования стратегического планирования региональной экономики инструментом изучения перспективных состояний показателя «Доходы консолидированного бюджета субъекта РФ» должна стать комплексная детализированная экономическая модель управляющего типа, охватывающая все секторы региональной экономики и учитывающая ее территориальную структуру. Суть региональной управляющей модели - это изучение характера и силы связей между факторными признаками (показателями социально-экономического развития региона) и результативными признаками (бюджетными данными, например, группами доходов консолидированного бюджета субъекта РФ), детализированными по отраслевому и территориальному признаку. Это обусловлено также тем, что процедура стратегического планирования в регионе не допускает шаблонного подхода, поскольку регионы отличаются друг от друга по различным характеристикам и условиям $[4$, с. $414 ; 5$, с. $98-105]$.

Необходимость применения территориально-отраслевого подхода к анализу и прогнозированию показателя «Доходы консолидированного бюджета субъекта РФ» заложена в его сущности. Доходами консолидированного бюджета субъекта РФ следует считать денежные средства, которые в соответствии с нормами российского законодательства поступают в бюджеты публично-правовых образований, расположенных на территории субъекта РФ, в результате возникновения денежных отношений между экономическими субъектами по поводу перераспре-

\section{Baikal Research Journal}


деления национального дохода и части национального богатства в действующих экономических условиях.

При изучении вопросов анализа и предвидения исследуемого явления наше внимание сфокусировано на параметрах консолидированного бюджета субъекта РФ, что объясняется их наилучшим соответствием требованиям, предъявляемым к показателям, включаемым в региональную управляющую модель. Так, при оценке социально-экономической ситуации в регионе и выработке механизмов социально-экономического регулирования параметры консолидированного бюджета субъекта РФ несут основную информационную нагрузку. Кроме того эти показатели более полно и обобщенно (по сравнению с показателями бюджета субъекта РФ и местных бюджетов в отдельности) отражают качество бюджетного процесса, реализуемого на территории конкретного региона и результативность выполняемых участниками бюджетного процесса бюджетных полномочий, в том числе высшего органа исполнительной власти субъекта РФ.

Поскольку стадия прогнозирования во многом определяет принятие дальнейших решений [6, с. 33], бюджетный процесс на территории субъекта РФ должен осуществляться на основе достоверных данных стратегий социально-экономического развития территорий $[7$, c. 47]. Интеграция стратегического и бюджетного планирования является важнейшим принципом реализации современного программно-целевого бюджетирования на региональном уровне [8, с. 13-16]. Таким образом, для повышения точности расчетов доходной части бюджетов необходима разработка информационно-методического обеспечения регионального стратегического планирования [9].

Качественные характеристики показателей консолидированного бюджета субъекта РФ делают их широко используемыми на практике. В частности они учитываются при формировании прогноза Российской Федерации и субъекта РФ на долгосрочный период, при построении системы межбюджетных отношений между публично-правовыми образованиями с целью обеспечения сбалансированности их бюджетов (например, при определении показателей бюджетной обеспеченности, нормативов отчислений от регулирующих доходов). Прогноз основных характеристик (общий объем доходов, общий объем расходов, дефицита (профицита) бюджета) консолидированного бюджета соответствующей территории на очередной финансовый год и плановый период либо утвержденный среднесрочный финансовый план представляется в качестве материалов одновременно с проектом бюджета ${ }^{1}$.

Важным свойством доходов консолидированного бюджета субъекта РФ является более высокий уровень сопоставимости показателя по сравнению с конкретным бюджетом публично-правового образования, ввиду отсутствия влияния перераспределительных отношений между бюджетом субъекта РФ и бюджетами муниципальных образований в части передачи дополнительных нормативов отчислений по доходам. Полученные в модели результаты прогнозирования достаточно скорректировать на нормативы распределения доходов, установленные налогово-бюджетным законодательством, и получить данные для соответствующего бюджета бюджетной системы РФ.

Выделенные свойства показателей консолидированного бюджета субъекта РФ делают их более пригодными для включения в региональную управляющую модель. Для осуществления прогноза региональных бюджетных доходов на научной основе имеются необходимые предпосылки: между событиями действительности существуют устойчивые причинно-следственные связи [10, с. 518]; существует закономерность (единообразие, повторяемость в окружающем мире) хода событий

${ }^{1}$ Бюджетный кодекс Российской Федерации. М. : Проспект, 2016. 320 с.

\section{Baikal Research Journal}

электронный научный журнал Байкальского государственного университета 
[10, с. 127]; существует знание связей и закономерностей явлений, а также знание констелляции событий в какой-то исходный момент времени ${ }^{2}$ [Там же, с. 136].

Учеными доказано наличие прямой корреляционной зависимости между величиной валового регионального продукта, доходами консолидированного бюджета субъекта Российской Федерации и среднедушевыми денежными доходами населения региона Российской Федерации [11, с. 232-236]. По доле доходов консолидированного бюджета субъекта РФ в валовом региональном продукте оценивается степень участия органов власти в экономической и общественной жизни региона, обусловленная стремлением к достижению не только әффективности, но и социальной и экономической справедливости в обществе.

Из рис. 1 видно, что удельный вес доходов консолидированного бюджета Иркутской области в валовом региональном продукте снижается с 17,8 \% в 2011 г. до $12,7 \%$ в 2015 г. Графическое представление динамики доли доходов консолидированного бюджета Иркутской области в валовом региональном продукте по видам доходов позволило обнаружить наличие в 2012-2015 гг. прямой линейной связи между результирующей (долей доходов консолидированного бюджета Иркутской области в валовом региональном продукте) и факторной (долей налоговых доходов в валовом региональном продукте) величинами. За анализируемый период снижается доля безвозмездных поступлений в валовом региональном продукте и, следовательно, уменьшается ее влияние на величину результативного признака.

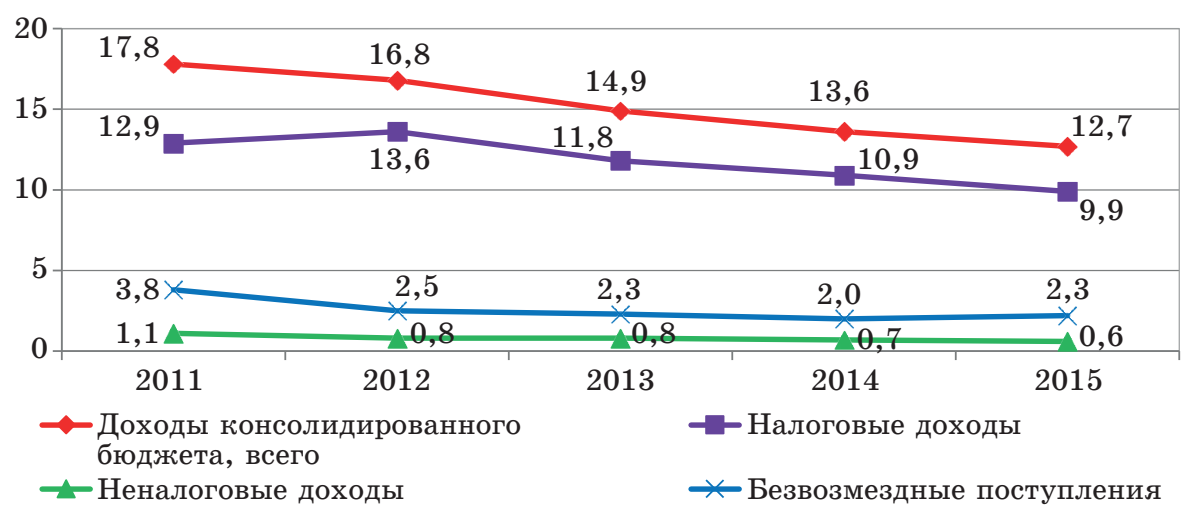

Рис. 1. Диналика доли доходов консолидированного бюджета Иркутской области в валовом региональном продукте за 2011-2015 г2., \%.

Составлено по даннылм Pосстата (URL: http://www.gks.ru/wps/wcm/connect/rosstat_ main/rosstat/ru/statistics/accounts/\#) и Казначейства Poccuи (URL: http://www. roskazna.ru/ispolnenie-byudzhetov/konsolidirovannye-byudzhety-subektov/1019/).

Снижение удельного веса доходов консолидированного бюджета Иркутской области в валовом региональном продукте может быть обусловлено изменениями в федеральном и региональном налогово-бюджетном законодательстве (в том числе под влиянием трансфертного ценообразования и создания консолидированных групп налогоплательщиков), а также может свидетельствовать о наличии неиспользуемого доходного потенциала консолидированного бюджета региона.

В отличие от федерального бюджета РФ, доходы которого больше подвержены влиянию нефтегазовых рентных источников, разовых эффектов от поступлений выручки от приватизации, доходы консолидированных бюджетов субъектов РФ более подвержены влиянию структурных изменений в экономике, происходящих

\footnotetext{
${ }^{2}$ Констелляция - в широком смысле это взаимное расположение и взаимодействие различных факторов, стечение обстоятельств.
}

\section{Baikal Research Journal}


под влиянием внешних и внутренних факторов. Данные изменения в экономике оцениваются по отраслевой структуре валового регионального продукта. На рис. 2 представлены отклонения в структуре валовой добавленной стоимости Иркутской области и в структуре поступлений налогов в консолидированный бюджет РФ с территории региона. За анализируемый период 2015 г. по сравнению с 2011 г. по большинству видов экономической деятельности ряды данных максимально приблизились, что подтверждает наличие «прямой корреляционной зависимости между величиной валового регионального продукта и доходами консолидированного бюджета субъекта РФ».

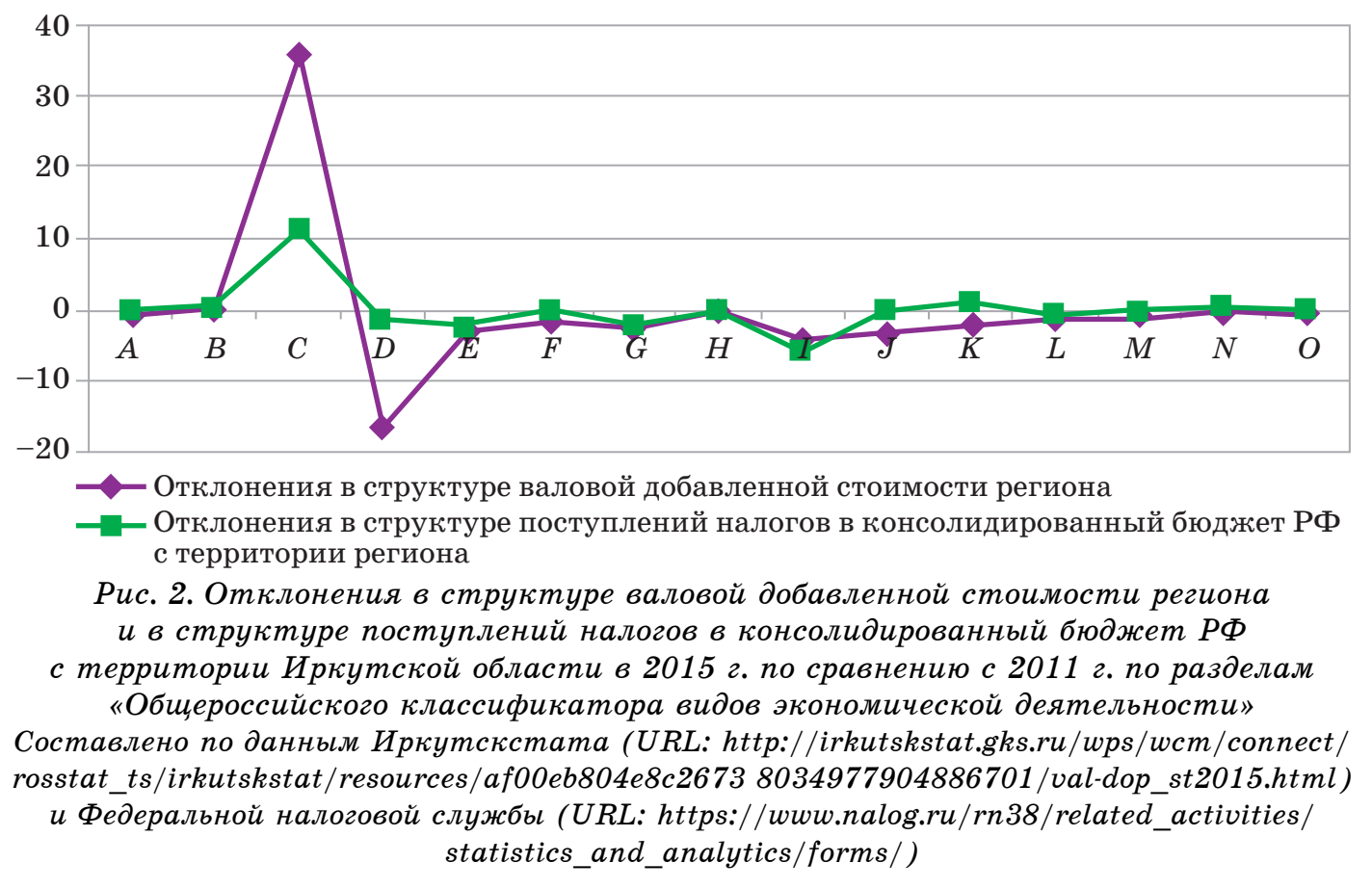

Вместе с тем, отсутствие показателей о поступлении налогов в консолидированный бюджет Иркутской области по видам экономической деятельности и использование в анализе сведений о поступлении налогов в консолидированный бюджет РФ с территории области исказило данные по отдельным отраслям на величину налогов, зачисляемых в федеральный бюджет (без учета налога на добавленную стоимость и налога на прибыль организаций, зачисляемого в федеральный бюджет). Также из факторов, вызвавших нарушение связей между рассматриваемыми явлениями, можно выделить влияние установленного порядка уплаты налогов. Например, уплата налога и авансовых платежей при применении упрощенной системы налогообложения производится по месту нахождения организации, то есть по месту ее государственной регистрации, а не по месту фактической деятельности (ст. 346.21 Налогового кодекса РФ).

Среди возможных причин, оказавших влияние на существенный разрыв связей между изучаемыми величинами по разделу $\mathrm{C}$ «Добыча полезных ископаемых» можно выделить следующие: создание консолидированных групп налогоплательщиков с минимизацией сумм налога на прибыль организаций $[12$, с. 89], и введение на уровне субъекта пониженных налоговых ставок по налогу на прибыль организаций, подлежащего зачислению в областной бюджет.

\section{Baikal Research Journal}


Резкий скачок доли отрасли «Добыча полезных ископаемых» в валовом региональном продукте обусловлен открытием и разработкой новых месторождений нефти и природного газа на территории Иркутской области. Это привело к увеличению доли первичного сектора экономики при сокращении других секторов, что отрицательно оценивается учеными [11, с. 236]. Такая однонаправленность экономики региона на высокодоходную отрасль «Добыча полезных ископаемых" может явиться причиной будущих проблем в социально-экономическом развитии субъекта РФ. С целью равномерного распределения доходного потенциала бюджетов публично-правовых образований региона и недопущения существенных диспропорций в социально-экономическом развитии административно-территориальных единиц региона от органов власти требуется сосредоточение усилий на развитии других отраслей экономики. Важным направлением этой политики может стать стимулирование роста тех производств третичного сектора, где создаются продукты с большой добавленной стоимостью и возникает обще- экономически сильный положительный эффект синергии [13, с. 102].

Наряду с отраслевым подходом к анализу и предвидению будущего состояния показателя «Доходы консолидированного бюджета субъекта РФ» нами обозначена необходимость учета и территориального подхода, который проявляется в двух аспектах. Во-первых, обязательность изучения показателя в разрезе административно-территориальных единиц, расположенных на территории субъекта. Во-вторых, единый методологический подход к его анализу и предвидению на уровне субъекта федерации и каждого муниципального образования, входящего в его состав.

Анализируя линии тренда, представленные на рис. 3 , можно предположить, что повышение качества прогноза доходов консолидированного бюджета Иркутской области за анализируемый период 2011-2015 гг. в большей степени зависит от качества прогноза по доходам бюджета субъекта РФ. Наряду с положительной динамикой повышения точности планирования областного бюджета Иркутской области видны недостатки прогнозирования местных бюджетов. Данные рис. 3 доказывают неэффективность разрозненного подхода к вопросам прогнозирования и планирования доходов бюджетов публично-правовых образований, расположенных на территории субъекта федерации.

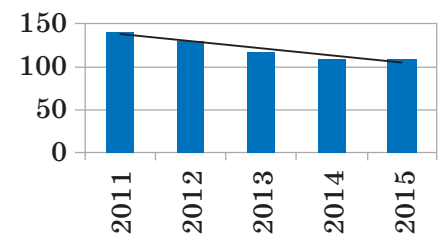

Консолидированный бюджет субъекта РФ

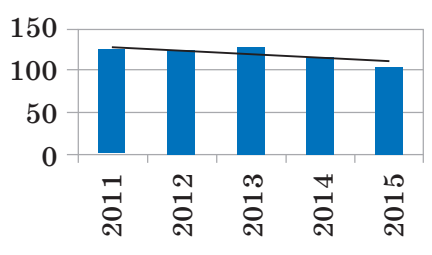

Бюджеты городских округов

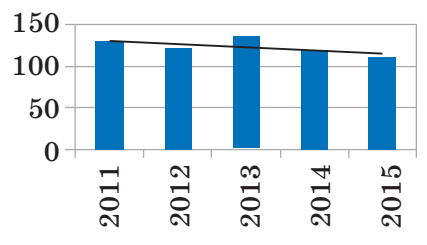

Бюджеты муниципальных районов

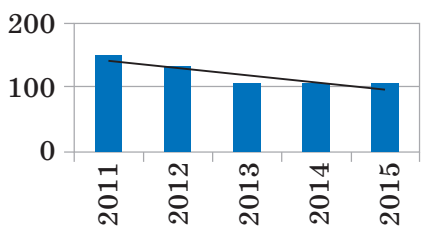

Бюджет субъекта РФ

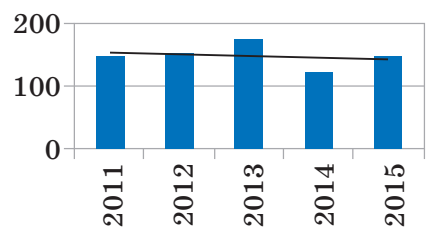

Бюджеты поселений

Рис. 3. Динамика выполнения плана по доходам консолидированного бюджета

Иркутской области в разрезе видов бюджетов за 2011-2015 г2., \%

Составлено по даннылм Казначейства России (URL: http://www.roskazna.ru/ispolneniebyudzhetov/konsolidirovannye-byudzhety-subektov/)

\section{Baikal Research Journal}


Разработка главными администраторами областного бюджета методик прогнозирования администрируемых доходов, повышение качества и полноты информации, предоставляемой налоговыми органами, связанное с изменениями в ст. 102 «Налоговая тайна» Налогового кодекса РФ позволили добиться к 2015 г. максимально точного прогноза по доходам консолидированного бюджета Иркутской области (рис. 4).

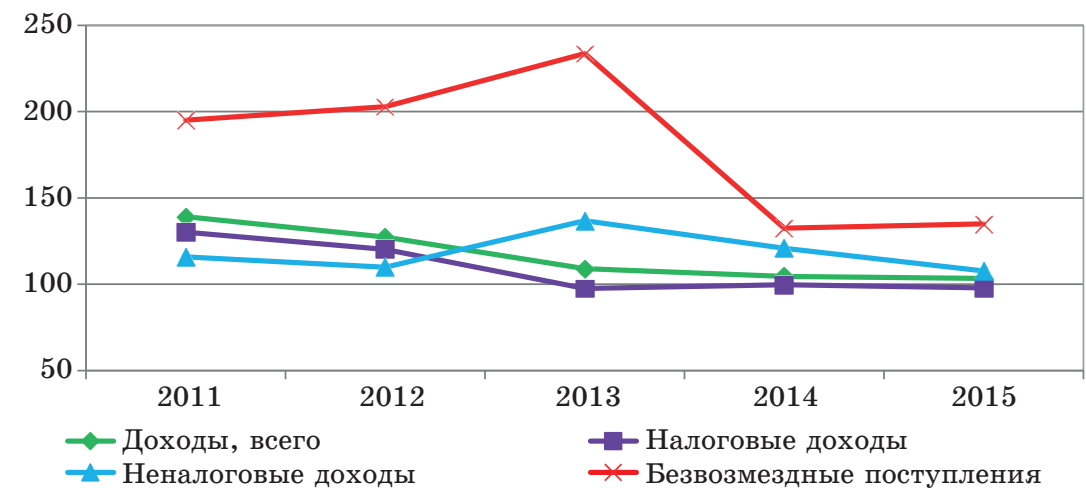

Рис. 4. Диналика выполнения первоначального плана

по доходам консолидированного бюджета Иркутской области

в разрезе групп доходов за 2011-2015 г2., \%

Составлено по данным Казначейства России (URL: http://www.roskazna.ru/ispolneniebyudzhetov/konsolidirovannye-byudzhety-subektov/)

Проведенный анализ показывает, что добиться регулярного получения точных вариативных прогнозов показателя «Доходы консолидированного бюджета субъекта РФ» на среднесрочную и долгосрочную перспективы возможно только основываясь на систематической оценке влияния на изучаемый параметр тех состояний, в которых экономика может оказаться после применения альтернативных комбинаций различных мер экономической политики, проводимой в региональной управляющей модели в территориально-отраслевом разрезе. Кроме того, это позволит связать три формы предвидения, различаемые учеными в зависимости от степени конкретности и характера воздействия на ход исследуемого явления (рис. 5): гипотезу (общенаучное предвидение), прогноз и план (программу) - последовательные в своей конкретности ступени познания поведения показателя «Доходы консолидированного бюджета субъекта РФ» в будущем.

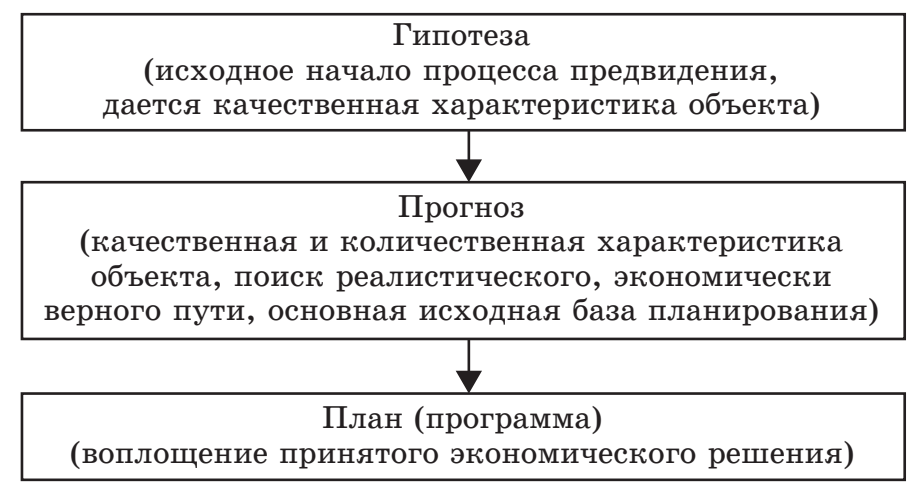

Рис. 5. Ступени познания изменений показателя «Доходы консолидированного бюджета субъекта РФ» в будущем

\section{Baikal Research Journal}


Изучив труды российских ученых [10; 14-17] нами определено, что прогнозирование доходов консолидированного бюджета субъекта РФ - это специальное научное исследование перспектив развития параметра «Доходы консолидированного бюджета субъекта РФ», детализированного по отдельным составляющим (группам доходов в территориально-отраслевом разрезе), проводимое участниками стратегического планирования во встроенном в региональную управляющую модель программном комплексе при информационном и методическом обеспечении со стороны информационно-аналитического центра.

В состав участников стратегического планирования доходов консолидированного бюджета субъекта РФ входят:

- высшее должностное лицо субъекта РФ, глава муниципального образования;

- законодательные (представительные) органы государственной власти субъекта РФ и представительные органы местного самоуправления (в том числе как главные администраторы доходов бюджета субъекта РФ и бюджетов муниципальных образований);

- исполнительные органы государственной власти субъекта РФ (исполнительно-распорядительные органы муниципальных образований) - главные администраторы (администраторы) доходов бюджета субъекта РФ и бюджетов муниципальных образований;

- территориальные органы (подразделения) федеральных органов исполнительной власти (как главные администраторы доходов бюджетов субъектов РФ, местных бюджетов и как источники информационно-аналитических данных);

- региональный информационно-аналитический центр.

Планирование доходов консолидированного бюджета субъекта РФ рассматривается нами в двух аспектах. Во-первых, как отражение и обоснование принятого управленческого решения - варианта прогноза в региональной управляющей модели с целью формирования в рамках бюджетного процесса реалистичных бюджетов публично-правовых образований региона по доходам. Результат планирования - план-бюджет. Во-вторых, как система взаимосвязанных плановых заданий для участников стратегического планирования, которые направлены на достижение единой цели - стопроцентного выполнения плана по доходам. В заданиях должны быть определены порядок, сроки и последовательность осуществления отдельных мероприятий. В плане фиксируются пути и средства развития в соответствии с поставленными задачами стратегического планирования, обосновываются принятые управленческие решения. Результат планирования - план-реализация, который принимает две формы: целевая программа и межотраслевой баланс «Доходы-расходы консолидированного бюджета субъекта РФ».

На рис. 6 представлен поэтапный алгоритм встраивания параметра «Доходы консолидированного бюджета субъекта РФ» в региональную управляющую модель.

Первый этап - передача органами государственной (муниципальной) власти фактической информации по $\mathrm{N}$-числу параметров модели (в том числе по законодательству) в информационно-аналитический центр, а также формирование в программном комплексе информационной базы данных.

Задача информационно-аналитического центра - осуществление постоянного сбора подробных и достоверных основных данных, удовлетворяющих требованиям для включения в модель. Сбор и предоставление специализированной информации в определенных областях органами государственной (муниципальной) власти должны осуществляться при строгом соблюдении стандартов, устанавливаемых информационно-аналитическим центром. Все это позволит добиться сопоставимости и совместимости данных, поступающих из различных источников, сократить количество временных и финансовых затрат, минимизировать потери ценной информации.

\section{Baikal Research Journal}

электронный научный журнал Байкальского государственного университета 


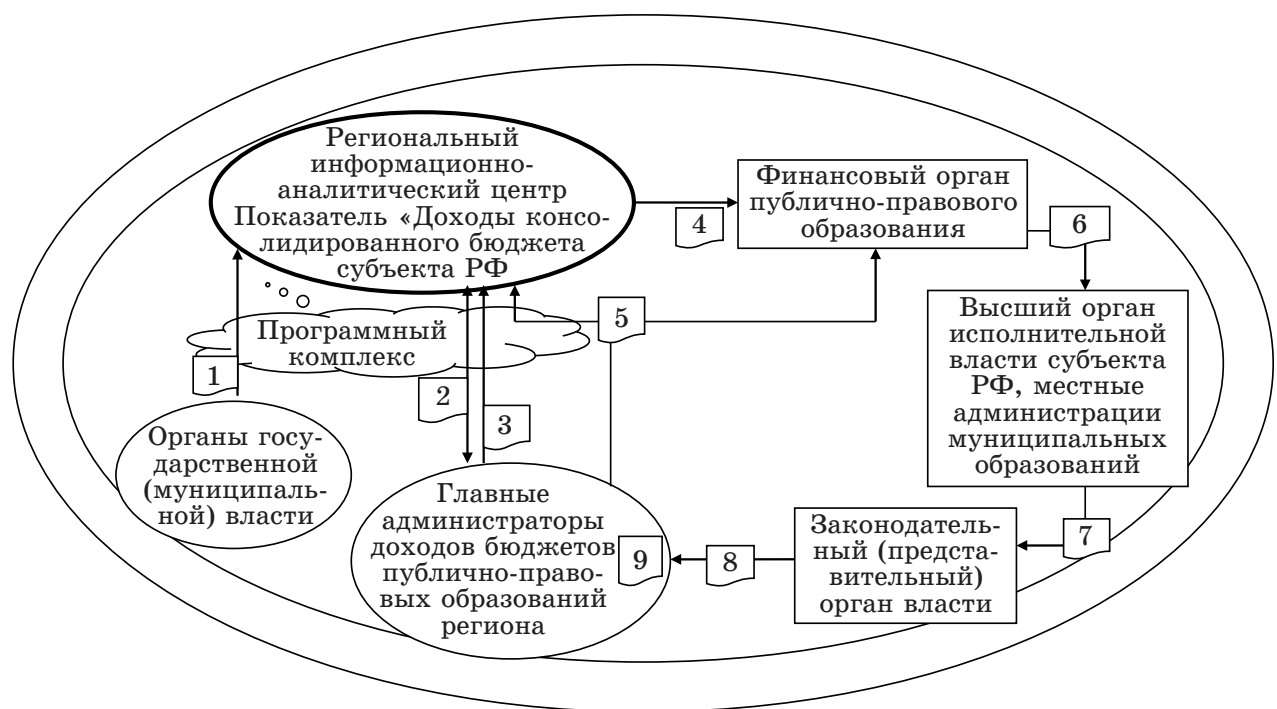

Рис. 6. Место паралетра «Доходы консолидированного бюджета субъекта РФ» в региональной управляющей модели

Второй этап - предоставление информационно-аналитическим центром доступа главным администраторам доходов бюджетов публично-правовых образований региона к информационной базе данных в специальном программном обеспечении и совместная разработка методического обеспечения процесса прогнозирования доходов.

Третий этап - прогнозирование по видам доходов в территориально-отраслевом разрезе. Этап реализуется главными администраторами доходов бюджетов публично-правовых образований региона в соответствии с закрепленными за ними полномочиями согласно нормам Бюджетного кодекса РФ в строгом соответствии с методическим обеспечением, разработанным и введенным в программный комплекс информационно-аналитическим центром на втором этапе.

Также на данном этапе информационно-аналитический центр консолидирует поступившие прогнозы и формирует прогноз доходов консолидированного бюджета субъекта РФ на вариантной основе, детализированный по главным администраторам доходов бюджетов и по группам доходов в территориально-отраслевом разрезе.

На четвертом этапе информационно-аналитический центр предоставляет финансовым органам публично-правовых образований региона доступ к прогнозу доходов консолидированного бюджета субъекта РФ на вариантной основе, детализированный по главным администраторам доходов бюджетов и по группам доходов в территориально-отраслевом разрезе. А также центр формулирует рекомендации по планированию доходов бюджетов публично-правовых образований.

Пятый этап реализуется финансовыми органами публично-правовых образований региона совместно с участниками стратегического планирования. На основании полученных в модели перспектив развития параметра «Доходы консолидированного бюджета субъекта РФ» финансовый орган осуществляет в программном комплексе выбор варианта прогноза и производит его корректировку на нормативы распределения, установленные налогово-бюджетным законодательством для соответствующего бюджета публично-правового образования.

На основе полученных в модели вариантов прогнозов доходов консолидированного бюджета субъекта РФ в территориально-отраслевом разрезе в соответствии с

\section{Baikal Research Journal}


утвержденными и включенными в модель методиками финансовый орган производит расчет межбюджетных трансфертов, получаемых и передаваемых бюджетами публично-правовых образований региона. Участниками стратегического планирования разрабатываются целевые программы, направленные на достижение утвержденных плановых заданий.

На шестом этапе финансовые органы на основании данных пятого этапа составляют в программном комплексе финансовые планы-бюджеты по доходам с последующим представлением в законодательный (представительный) орган власти.

На седьмом этапе после принятия законодательными (представительными) органами власти соответствующих бюджетов публично-правовых образований участники стратегического планирования утверждают целевые программы, направленные на достижение установленных плановых заданий. Также на данном этапе в информационно-аналитическом центре разрабатываются межотраслевые балансы по доходам и расходам консолидированного бюджета субъекта $P \Phi$ в целом и в территориальном разрезе.

Восьмой этап - реализация участниками стратегического планирования плановых документов шестого и седьмого этапов.

Реализация всех этапов производится под контролем специалистов информационно-аналитического центра в едином методическом и информационном поле. Это обеспечивает наиболее точный расчет плановых показателей доходов консолидированного бюджета субъекта РФ в рамках региональной управляющей модели, в которой координируются целенаправленным воздействием территориально-отраслевые связи между участниками процесса стратегического планирования на заданный период.

\section{Список использованной литературы}

1. Леонтьев В. В. Межотраслевая экономика / В. В. Леотьев ; науч. ред. А. Г. Гранберг. - М. : Экономика, 1997. - 479 с.

2. Краткосрочное прогнозировании регионального развития в условиях неполной информации / отв. ред. М. М. Албегов. - М. : Эдиториал УРСС, 2001. - 160 с.

3. Иркутская область в XXI веке: проблемы и ресурсы развития / А. П. Киреенко, С. В. Чупров, Л. В. Санина [и др.]. - Иркутск : Изд-во БГУЭП, 2014. - 422 с.

4. Кузык Б. Н. Прогнозирование, стратегическое планирование и национальное программирование : учебник / Б. Н. Кузык, В. И. Кушлин. Ю. В. Яковец. - 4-е изд., перераб. и доп. - М. : Экономика, 2011. - 604 с.

5. Вдовин С. М. Стратегия и механизмы устойчивого развития региона : монография / С. М. Вдовин. - М. : Инфра-М, 2016. - 154 с.

6. Безпалов В. В. Теория и практика управления развитием региональных экономических систем : монография / В. В. Безпалов, Л. А. Лочан, Д. С. Петросян. - М. : РУСАЙНС, 2016. - 236 с.

7. Индикативное планирование и проведение региональной политики / под общ. ред. А. Б. Левинталя, Ф. Ф. Пащенко. - М. : Финансы и статистика, 2007. - 368 с.

8. Соколов И. А. Программно-целевое управление бюджетом: опыт и перспективы в России : монография / И. А. Соколов, Т. В. Тищенко, А. А. Хрусталев. - М. : Дело, $2013-246 \mathrm{c}$.

9. Бабкин А. В. Проблемы стратегического планирования в региональном и муниципальном звене управления [Электронный ресурс] / А. В. Бабкин, Е. М. Бухвальд. - Режим доступа: http://institutiones.com/strategies/2637-problemy-strategicheskogo-planirovaniya.html.

10. Кондратьев Н. Д. Избранные сочинения / Н. Д. Кондратьев. - М. : Экономика, 1993. $-543 \mathrm{c}$.

11. Ковалева Т. Ю. Статистическое изучение зависимости доходов бюджета и населения от величины ВРП и взаимосвязь его динамики со структурными сдвигами в секторах экономики регионов РФ / Т. Ю. Ковалева // Проблемы современной экономики. 2015. - № 2 (54). - C. 232-236.

\section{Baikal Research Journal}


12. Кремповая Н. Л. Влияние создания консолидированных групп налогоплательщиков на доходы бюджетов Российской Федерации / Н. Л. Кремповая // Символ науки. 2015. - № 4. - С. 89-91.

13. Перепелкин В. А. Динамическая модель анализа секторной структуры национальных экономик с сырьевой специализацией экспорта / В. А. Перепелкин, Е. В. Перепелкина // Самарский научный вестник. — 2015. - № 1 (10). - С. 98-103.

14. Ковалева Т. М. Бюджетная политика и бюджетное планирование в Российской Федерации : учеб. пособие / Т. М. Ковалева. - М. : КноРус, 2009. - 128 с.

15. Прогнозирование будущего: новая парадигма / под ред. Г. Г. Фетисова, В. М. Бондаренко. - М. : Экономика, 2008. - 283 с.

16. Дуброва Т. А. Прогнозирование социально-экономических процессов. Статистические методы и модели : учеб. пособие / Т. А. Дуброва. - М. : Маркет ДС, 2007. - 192 с.

17. Афанасьев В. Н. Статистические методы прогнозирования в экономике: учеб.-метод. пособие / В. Н. Афанасьев, Т. В. Лебедева. - М. : Финансы и статистика, 2009. — 180 с.

\section{References}

1. Leontyev V.; Granberg A. G. (ed.). Mezhotraslevaya ekonomika [Cross-Sector Economy]. Moscow, Economika Publ., 1997. 479 p.

2. Albegov M. M. (ed.). Kratkosrochnoe prognozirovanii regional'nogo razvitiya $v$ usloviyakh nepolnoi informatsii [Short-term forecasting of regional development in terms of incomplete information]. Moscow, Editorial URSS Publ., 2001. 160 p.

3. Kireenko A. P., Chuprov S. V., Sanina L. V. et al. Irkutskaya oblast' $v$ XXI veke: problemy $i$ resursy razvitiya [Irkutsk Oblast in the 21st century: problems and development resources]. Irkutsk, Baikal State University of Economics and Law Publ., 2014. 422 p.

4. Kuzyk B. N., Kushlin V. I., Yakovets Yu. V. Prognozirovanie, strategicheskoe plan irovanie i natsional'noe programmirovanie [Forecasting, strategic planning and national programming]. $4^{\text {th }}$ ed. Moscow, Ekonomika Publ., 2011. 604 p.

5. Vdovin S. M. Strategiya $i$ mekhanizmy ustoichivogo razvitiya regiona [Strategy and mechanisms of regional sustainable development]. Moscow, Infra-M Publ., 2016. $154 \mathrm{p}$.

6. Bezpalov V. V, Lochan L. A., Petrosyan D. S. Teoriya i praktika upravleniya razvitiem regional'nykh ekonomicheskikh sistem [Theory and practice of development management for regional economic systems]. Moscow, RUSAINS Publ., 2016. 236 p.

7. Levintal A. B., Pashchenko F. F. (eds). Indikativnoe planirovanie i provedenie regional'noi politiki [Indicative planning and performance of regional policy]. Moscow, Finansy i statistika Publ., 2007. 368 p.

8. Sokolov I. A., Tishchenko T. V., Khrustalev A. A. Programmno-tselevoe upravlenie byudzhetom: opyt $i$ perspektivy $v$ Rossii [Program-targeted management of business: experience and prospects in Russia]. Moscow, Delo Publ., 2013. 246 p.

9. Babkin A. V., Bukhvald E. M. Problemy strategicheskogo planirovaniya $v$ regional'nom $i$ munitsipal'nom zvene upravleniya [Problems of strategic planning in regional and municipal link of management]. Available at: http://institutiones.com/strategies/2637-problemy-strategicheskogo-planirovaniya.html. (In Russian)

10. Kondratyev N. D. Izbrannye sochineniya [Selected Works]. Moscow, Ekonomika Publ., 1993. $543 \mathrm{p}$.

11. Kovaleva T. Yu. Statistical study of dependency of budget and population's revenue on the Gross Regional Product, and the mutual relation of its dynamics with the structural shifts in various sectors of economy in the Russian Federation regions. Problemy sovremennoi ekonomiki = Problems of Modern Economy, 2015, no. 2 (54), pp. 232-236. (In Russian).

12. Krempovaya N. L. Influence of creating of taxpayers' consolidated groups on income of the Russian Federation budgets. Simvol nauki $=$ Symbol of Science, 2015, no. 4, pp. 89-91. (In Russian)

13. Perepelkin V. A., Perepelkina E. V. Dynamic model of analyzing sectoral structure of national economies with raw material export specialization. Samarskii nauchnyi vestnik= Samara Journal of Science, 2015, no. 1 (10), pp. 98-103. (In Russian)

14. Kovaleva T. M. Byudzhetnaya politika i byudzhetnoe planirovanie $v$ Rossiskoi Federatsii [Budget policy and budget planning in the Russian Federation]. Moscow, KnoRus Publ., 2009. $128 \mathrm{p}$.

\section{Baikal Research Journal}

электронный научный журнал Байкальского государственного университета 
15. Fetisov G. G., Bondarenko V. M. (eds). Prognozirovanie budushchego: novaya paradigma [Forecasting of the future: a new paradigm]. Moscow, Ekonomika Publ., 2008. 283 p.

16. Dubrova T. A. Prognozirovanie sotsial'no-ekonomicheskikh protsessov. Statisticheskie metody $i$ modeli [Forecasting of socio-economic processes. Statistical methods and models]. Moscow, Market DS Publ., 2007. 192 p.

17. Afanasyev V. N., Lebedeva T. V. Statisticheskie metody prognozirovaniya $v$ ekonomike [Statistical methods of forecasting in economy]. Moscow, Finansy i statistika Publ., 2009. 180 p.

\section{Информация об авторах}

Бычкова Марина Сергеевна - аспирант, кафедра финансов, Байкальский государственный университет, 664003, г. Иркутск, ул. Ленина, 11, e-mail: skvo-marina1@yandex.ru.

Сорокина Татьяна Владимировна - доктор экономических наук, доцент, кафедра финансов, Байкальский государственный университет, 664003, г. Иркутск, ул. Ленина, 11, e-mail: natvros@mail.ru.

\section{Authors}

Marina S. Bychkova - PhD Student, Chair of Finance, Baikal State University, 11, Lenin St., 664003, Irkutsk, Russian Federation; e-mail: skvo-marina1@yandex.ru.

Tatiana V. Sorokina - Doctor habil. (Economics), Associate Professor, Chair of Finance, Baikal State University, 11, Lenin St., 664003, Irkutsk, Russian Federation; e-mail: natvros@mail.ru.

\section{Библиографическое описание статьи}

Бычкова М. С. Особенности прогнозирования и планирования доходов консолидированного бюджета субъекта Российской Федерации на основе региональной управляющей модели / М. С. Бычкова, Т. В. Сорокина // Baikal Research Journal. - 2017. - T. 8, № 1. - DOI: 10.17150/2411-6262.2017.8(1).6.

\section{Reference to article}

Bychkova M. S., Sorokina T. V. Features of forecasting and planning of income in consolidated budget of the Russian Federation entity on the basis of regional operating model. Baikal Research Journal, 2017, vol. 8, no. 1. DOI: 10.17150/2411-6262.2017.8(1).6. (In Russian).

\section{Baikal Research Journal}

